\title{
Lembranças do golpe - 1964
}

\author{
Maria Paula Nascimento Araujo*
}

Neste artigo apresentaremos, em forma escrita, trechos de depoimentos de um acervo áudiovisual. Acompanha o artigo um vídeo feito a partir da edição das imagens referentes a esses trechos. Dessa forma, o leitor poderá ler os trechos dos depoimentos e/ou assistir ao vídeo com esses mesmos trechos. No vídeo, as falas dos depoentes foram traduzidas para legendas em inglês. ${ }^{1}$

Os pequenos trechos de depoimentos apresentados aqui foram retirados do acervo "Marcas da memória: história oral da anistia no Brasil", que reúne entrevistas de pessoas que tiveram suas vidas marcadas, de alguma forma, pela ditadura militar brasileira: ex-presos políticos, ex-banidos e exilados, familiares de mortos e desaparecidos, militantes de organizaçóes de esquerda e de movimentos de direitos humanos, padres, advogados de presos políticos, entre outros. As entrevistas foram gravadas, filmadas, editadas e transcritas e constituem um importante acervo audiovisual para a pesquisa sobre a história e a memória da ditadura militar e do processo de redemocratização e justiça de transição no Brasil.

A construção desse acervo audiovisual foi o resultado de um convênio estabelecido entre a Comissão de Anistia do Ministério da Justiça e três universidades federais - a de Pernambuco (UFPE), a do Rio Grande do Sul (UFRGS) e a do Rio de Janeiro (UFRJ). A equipe do Rio de Janeiro, coordenada a partir da UFRJ, realizou 60 entrevistas na regiáo Sudeste - Belo Horizonte, Juiz de Fora, São Paulo, Volta Redonda e, principalmente, Rio de Janeiro. As entrevistas realizadas pela equipe da UFRJ estão disponíveis no Laboratório de Estudos do Tempo Presente do Instituto de História da UFRJ. Esse acervo tem servido de fonte para a pesquisa da história política recente do país e também para a elaboração de material paradidático para subsidiar professores do ensino fundamental e médio no debate sobre esse período.

A história oral é uma importante ferramenta para o historiador do tempo presente. Os depoimentos são fundamentais para o entendimento das representaçóes subjetivas de uma época, do significado de vivências e experiências e das disputas entre as diferentes memórias.

\footnotetext{
"Doutora em ciência política pelo Iuperj, professora associada da Universidade Federal do Rio de Janeiro e bolsista de produtividade CNPq, nível 2. Rio de Janeiro, RJ, Brasil. E-mail: mpaula.araujo@globo.com.

${ }^{1}$ A equipe do projeto Marcas da Memória, formada por estudantes de graduação do Instituto de História da UFRJ, colaborou na seleção, transcrição e edição dos depoimentos deste artigo: Ana Caroline Alencar, Gabriela Machado, Isadora Gomes e Renato Dias.
} 
Eles permitem ao historiador analisar o que move, para além das relaçôes sociais estabelecidas, o cotidiano, as experiências banais e ordinárias de vida, os investimentos de sentido nas escolhas existenciais, as relaçóes de amor, parceria, cumplicidade ou, ao contrário, de rejeição, desafeto, competição. Ou seja, as relaçôes entre os projetos individuais e o horizonte histórico de real possibilidade de concretização desses projetos.

Nosso acervo foi constituído a partir da diretriz de Maurice Halbwacks. Selecionamos nossos depoentes a partir do pertencimento a "comunidades afetivas". Como apontou Halbwacks, ${ }^{2}$ a construção da memória é um processo social, coletivo, que envolve pessoas pertencentes a um determinado grupo - a uma comunidade afetiva - como a família, um grupo de trabalhadores ligados a um sindicato, uma turma universitária, militantes de um mesmo partido, ou seja, um grupo de referência, no qual foram vividas determinadas experiências e no interior do qual foram construídas determinadas lembranças. Halbwacks afirma que "lembramos melhor" em grupo do que quando estamos sozinhos, porque o processo de construção de memória é, eminentemente, coletivo. É o grupo, num processo coletivo de seleção, que escolhe o que lembrar e o que esquecer. Por isso tivemos a preocupaçáo de selecionar nossos depoentes procurando grupos e referências mais gerais: entrevistamos várias pessoas que poderiam ter suas "comunidades de pertencimento" classificadas como diferentes partidos políticos, movimentos sociais, segmentos profissionais, grupos artísticos, entre outras classificaçóes. E procuramos, em cada uma dessas "comunidades", realizar certo número de entrevistas para que se pudessem ter elementos para perceber o processo social de construção de memória daquele grupo em questão.

Construído dessa forma, o acervo nos evidenciou alguns eixos de análise importantes. $\mathrm{O}$ primeiro deles refere-se às disputas pelo enquadramento da memória do passado. Michael Pollak nos mostrou que, além da dimensão coletiva da memória, sua construção social é permeada de disputas e conflitos resultando em "memórias dominantes" e em "memórias subterrâneas" - memórias dominadas, envergonhadas, temas tabus e interditos que pemanecem ocultos durante longo tempo, até que novas questóes e demandas do presente permitam a sua emersão. ${ }^{3} \mathrm{~A}$ análise de nosso acervo permite detectar essas disputas de memória e de versóes sobre o passado. Talvez uma das mais evidentes seja justamente a memória do próprio golpe e do movimento político do pré-64. Para uns, o momento áureo da democracia brasileira, para outros, o período do "populismo" e de uma tática política ilusória tendente ao fracasso. Essa disputa de memória corresponde a disputas de visóes de grupos políticos atuantes na época e subsiste na memória atual do período. No entanto, para análise dessas disputas de memória, é importante também ter em mente a questão estratégica do esquecimento tal como apontada por Andreas Huyssen. ${ }^{4}$ Huyssen enfatizou que a relação

\footnotetext{
${ }^{2}$ HALBWACKS, Maurice. A memória coletiva. São Paulo: Vértice, 1990.

${ }^{3}$ POLLAK, Michael. Memória, esquecimento, silêncio. Estudos Históricos, Rio de Janeiro, v. 2, n. 3, p. 3-15, 1989.

${ }^{4}$ HUYSEN, Andreas. Resistência à memória: usos e abusos do esquecimento público. Porto Alegre, 2004. Mimeografado.
} 
entre memória e esquecimento é complexa e estratégica. O que se "escolhe" para lembrar ou esquecer depende das demandas do presente. Memória e esquecimento não se opóem de forma simplista e maniqueísta (onde a memória representa sempre o lado "positivo" e o esquecimento o "negativo"). Para Huyssen, o esquecimento é, muitas vezes, resultado de opçóes e estratégias mais ou menos conscientes de pessoas e grupos da sociedade e que mudam em função das demandas e possibilidades do presente.

Outro eixo de análise importante propiciado pelo acervo é dado pela perspectiva de explorar as histórias de vida narradas pelos depoentes. Esses relatos de "histórias de vida" permitem ao historiador compreender "a história a partir de múltiplas histórias de vida". Num livro que foi pioneiro nos estudos biográficos, intitulado História e histórias de vida: o método biográfico nas ciências sociais, ${ }^{5}$ Ferrarotti chamou a atenção para a relação entre a história e as múltiplas histórias individuais e a possibilidade que daí decorre de ler uma sociedade através de uma ou muitas biografias.

$\mathrm{O}$ ato de narrar a vida, compartilhando suas lembranças e experiências, principalmente quando elas estão relacionadas a um passado de violência política, como bem apontou Elizabeth Jelin, constitui um "trabalho de memória". ${ }^{6}$ Esse trabalho implica não apenas uma rememoração e repetição do vivido, mas também uma relação com o presente e uma projeção para o futuro. Dessa forma, um acervo de depoimentos como o nosso permite também perceber e analisar como questóes do presente, relativas à política e à justiça, aparecem nas falas de nossos depoentes.

A história oral tem sido utilizada como ferramenta para enfrentar a questão do trauma político. Nas últimas décadas, têm-se produzido inúmeros estudos a partir da história oral, sobre o trauma político provocado por regimes violentos e autoritários, dando voz às vítimas de violências perpetradas pelo Estado e também pela sociedade, e produzindo testemunhos sobre o passado autoritário, contribuindo, muitas vezes, para procedimentos de memória e justiça em países que procuram superar contextos de violência política.

Em seu livro Writing history, writing trauma, Dominick LaCapra afirma que o depoimento traz para a história um conhecimento específico do passado:

La importancia de los testimonios se hace más evidente cuando se piensa en que aportan algo que no es idéntico al conocimiento puramente documental. Los testimonios son importantes cuando se intenta comprender la experiencia y sus consecuencias, incluido el papel de la memoria y los olvidos en que se incurre a fin de acomodarse al pasado, negarlo o reprimirlo.?

\footnotetext{
${ }^{5}$ FERRAROTTI, Franco. Histoire et histoires de vie: la méthode biographique dans les sciences sociales. Paris: Librairie des Meridiens, 1983

${ }^{6}$ JELIN, Elizabeth. Los trabajos de la memoria. Madri; Buenos Aires: Siglo Veintiuno, 2002. (Memorias de la represión).

${ }^{7}$ Como o livro não foi traduzido no Brasil utilizamos a edição argentina: Escribir la historia, escribir el trauma, lançado pela editora Nueva Visión em 2005, Buenos Aires.
} 
Os trechos apresentados neste artigo são as respostas que alguns dos nossos depoentes deram à pergunta: "quais as lembranças que você tem do dia do golpe?".

As respostas são variadas, mas uma questão salta aos olhos na leitura de muitos depoimentos: quando o golpe ocorreu, ninguém tinha uma ideia clara da dimensão do que estava acontecendo; a esquerda e os vários setores do movimento sindical e popular, do movimento estudantil, assim como intelectuais e artistas envolvidos na campanha pelas reformas de base conduzida pelo governo de João Goulart não esperavam o golpe.

O único depoimento divergente e contundente sobre esse tema é o de Clara Charf, viúva de Carlos Marighella, na época membro do Comitê Central do Partido Comunista Brasileiro (PCB). Em seu depoimento, Clara afirma que Marighella "sabia" que o golpe ia acontecer. Sua forte intuição teria sido responsável pela fuga do casal, que conseguiu, naquele momento, escapar da polícia. Três anos mais tarde, em 1967, Marighella rompeu com o PCB, acusando o partido de imobilismo em face da ditadura militar e no ano seguinte criou a organização de luta armada Ação Libertadora Nacional (ALN). Marighella foi morto por agentes do Dops em 1969.

Mas essa certeza sobre a iminência do golpe aparece apenas no depoimento de Clara Charf. Os outros depoimentos evidenciam surpresa e perplexidade. A historiadora Dulce Pandolfi, na época estudante secundarista em Recife, dá a dimensão de como o golpe era inesperado, principalmente em Pernambuco, o estado governado por Miguel Arraes, que levava adiante o Movimento de Educaçáo de Base, com a metodologia de Paulo Freire, voltada para a emancipação dos trabalhadores urbanos e rurais: "porque a esquerda tinha a grande ilusão de que as suas forças eram maiores do que eram de fato e de que nada barraria aquele avanço do progresso". ${ }^{8}$

O depoimento de Clarice Herzog, viúva do jornalista Vladimir Herzog, expóe como essa subestimação em relação ao golpe e à ditadura pode ser trágica. Clarice e Vlado, como era conhecido o jornalista, saíram do país na ocasião do golpe; mas a violência, a força e a durabilidade da ditadura na estavam claras para o casal. Após alguns anos em Londres, o casal voltou com dois filhos. Em 1974, Vladimir Herzog foi preso e assassinado na cadeia. O governo apresentou a versão de um suicídio. Clarice passou anos tentando provar que havia sido assassinato. Recorreu ao sindicato dos jornalistas e a inúmeros advogados e, ao final, conseguiu provar que seu marido tinha sido assassinado no Dops. A viúva de Herzog tornou-se um símbolo da luta dos familiares de mortos e desaparecidos e foi imortalizada pelos versos da canção de Joâo Bosco e Aldir Blanc ("choram Marias e Clarices no solo do Brasil").

Os testemunhos de Anita Prestes (filha de Luís Carlos Prestes do PCB e de Olga Benário, comunista alemá e judia que a ditadura de Getúlio Vargas enviou para a Gestapo) e de Ferreira Gullar (poeta, escritor e dramaturgo, diretor do Centro Popular de Cultura da

\footnotetext{
${ }^{8}$ Depoimento de Dulce Pandolfi. Acervo "Marcas da memória”, UFRJ.
} 
União Nacional dos Estudantes — o CPC da UNE) falam da interrupção de projetos de vida: projetos políticos, projetos individuais e geracionais.

Mas no depoimento de Flavia Schilling, professora de Educação da Universidade de São Paulo (USP), aparece uma lembrança do golpe que a sociedade atual procura esquecer. Flavia era criança na época, filha de Paulo Schilling, político ligado a João Goulart. A família toda se exilou no Uruguai e nesse país Flavia se ligou à organização dos Tupamaros e foi presa. A lembrança de Flavia do dia do golpe é a imagem das velas acesas dos moradores do Leblon, orando pela "derrota dos comunistas e do governo Goulart". ${ }^{9}$ O apoio de significativos setores da população é algo que hoje se procura apagar da memória social.

Os depoimentos nos mostram como o golpe irrompeu no meio do cotidiano das pessoas, no meio de um projeto político de reformas sociais, no meio da vida universitária, no meio da vida das famílias. Poucos tinham a dimensão da mudança que ocorreria na vida do país e da durabilidade do regime golpista que estava sendo implantado.

A história oral é uma metodologia que permite ao historiador conhecer a memória socialmente construída de episódios relevantes do passado. Essa construção não apenas é marcada por conflitos, disputas, contradiçóes como filtrada pelas questôes e demandas do presente. Além disso, os depoimentos nos abrem uma porta que permite encarar a subjetividade como um elemento da história - de uma época, de um grupo de pessoas, de uma geração e, dessa forma, ter acesso a experiências humanas em diferentes contextos sociais.

A riqueza e a capacidade mobilizadora dos depoimentos coloca para o historiador um desafio: ser capaz de valorizar a riqueza da fonte oral mas manter, ao mesmo tempo, o distanciamento crítico. A história oral deve fugir do terreno da pura exaltação da subjetividade; procurando não se "colar" à fala do depoente, não ser subjugada pela força da fala na primeira pessoa. Deve ser capaz, por mais difícil que seja, principalmente nos depoimentos que se referem a momentos de grande violência política, de exercer a crítica e a reflexão.

Dominick LaCapra se debruçou sobre esse problema. Para LaCapra o historiador que trabalha com testemunhos converte-se, ele próprio, numa testemunha secundária (testigo secundário), porque tem acesso, em primeira mão, a um relato/registro do passado, que só pode ser conhecido por meio daquele testemunho que, de certa forma, revive os acontecimentos traumáticos que relata. ${ }^{10} \mathrm{LaCapra}$ enfatiza que a empatia do historiador com as testemunhas não pode se transformar em identificação. A postura ética do historiador seria, essencialmente, a de reconhecer a alteridade do outro, dar espaço para a singularidade de sua experiência traumática. Não se confundir com a fala do depoente seria, portanto, uma atitude de respeito ao próprio depoente e ao testemunho que ele dá. O trabalho com a história oral exige, portanto, do historiador uma atenção. Suas fontes são pessoas vivas, de carne e osso, que aceitam dar seus depoimentos e reviver lembranças muitas vezes dolorosas; que

\footnotetext{
${ }^{9}$ Depoimento de Flavia Schilling. Acervo "Marcas da memória", UFRJ.

${ }^{10}$ LACAPRA, Dominick. Escribir la historia, escribir el trauma, op. cit. p. 115.
} 
LEMBRANÇAS DO GOLPE - I964

Maria Paula Nascimento Araujo

aceitam também inserir suas memórias e discursos em processos contemporâneos de disputas políticas. Ao mesmo tempo esses depoimentos trazem uma riqueza imensa decorrente justamente da narrativa do passado vivido. Colher estes depoimentos, organizá-los, divulgá-los e analisá-los é um desafio dos historiadores do tempo presente.

\section{Depoimentos Marcas da memória}

TRECHOS SELECIONADOS

\section{Anita Leocádia Prestes}

Filha dos comunistas Olga Benário e Luíz Carlos Prestes. Olga foi executada em um campo de concentraçáo pelo governo nazista e Prestes foi um importante líder comunista idealizador da Coluna Prestes. Anita, a entrevistada, nasceu no campo de concentraçáo e foi salva da execuçáo por uma campanha internacional promovida pela família de seu pai. Ela foi perseguida antes e durante a ditadura militar e só conseguiu se estabilizar no Brasil após a Anistia de 1979.

Bom, falava-se muito em golpe e ninguém acreditava muito que realmente fosse haver um golpe. Havia muita boataria. Não vou fazer uma análise da situação, que seria longa e demorada, mas realmente foi um baque muito grande para todas as forças de esquerda. Começou logo uma perseguição muito grande e cortou a vida de todo mundo, quer dizer, os projetos que nós jovens tínhamos. Primeiro o partido foi posto fora da lei, os comunistas perseguidos, todo aquele movimento estudantil perseguido, a UNE [União Nacional dos Estudantes] foi incendiada, logo todas aquelas atividades foram por água abaixo, uma perseguição muito grande. Por outro lado, os projetos pessoais também: eu mesma estudava química nessa época e me formei nesse ano de 64, já tinha feito prática, estágio, na fábrica de borracha da Petrobras em Duque de Caxias, acho que ainda tem essa fábrica. Então já estava tudo encaminhado para assim que eu me formasse ir trabalhar lá, que era uma coisa que me parecia muito interessante, não só pelas possibilidades de pesquisa ligadas à indústria de borracha, no caso de petróleo, mas também o trabalho sindical, que era muito forte e interessante. Mas aí tudo isso foi por água abaixo porque inclusive todas as pessoas de esquerda que trabalhavam na Petrobras foram postas para fora, expulsas ou presas. Foi assim, uma reviravolta total na vida, náo só minha como daquele pessoal que estava participando do movimento na época, foi assim muito impactante realmente. Nos primeiros meses a gente ainda tinha esperança de uma reação, depois ficou claro que não, que realmente a ditadura tinha vindo para ficar e ficou por vinte anos, não foi brincadeira. 


\section{Clara Charf}

\section{É viúva de Carlos Marighella. Militou no Partido Comunista Brasileiro (PCB) e na} Açáo Libertadora Nacional (ALN). Viveu na clandestinidade por longos anos. Foi exilada após a morte de Marighella e, posteriormente, anistiada. Teve grande participaçáo política no PT, atuando, sobretudo, em questóes como o direito das mulheres e os direitos humanos. Seu processo foi deferido pela Comissáo de Anistia.

A gente morava naquele tempo perto do palácio do Catete, na rua Correia Dutra; a gente morou muito tempo ali, muitos anos. O período em que a gente viveu com mais liberdade, que eu era Clara Charf e ele Carlos Marighella, foi naquela rua, na Correia Dutra, desde o tempo de Juscelino até quando veio o Golpe. A gente morou ali. A gente foi vivendo toda a situação, Carlos Lacerda, toda a perseguição já havia em função de conflitos, e o Marighella que tinha toda essa visão de que o Golpe estava sendo preparado, começou a discutir com outros companheiros de que o Partido precisava se preparar e a direção do Partido... O Prestes dizia que "Eles podem dar o Golpe mas, vão ter as cabeças cortadas". Não foi nada disso, né? O Golpe veio, a polícia invadiu o apartamento onde a gente morava. Como o Marighella tinha essa sensação, essa ideia e essa compreensão de que o Golpe estava sendo preparado, ele conversou com os companheiros operários que moravam na periferia e disse: "Olha, qualquer coisa eu vou para a casa de vocês". Isso era um esquema que ele já tinha montado. Veio o Golpe, parece que havia uma coisa dizendo: "Vocês saiam daí, porque o apartamento vai ser invadido". Um dia, ele chegou em casa - já nessa situação tensa - e disse: "Clara, vamos embora. Vamos pegar umas coisas aqui, porque eu acho que o Golpe vai ser deflagrado já!”. Nós morávamos no sétimo andar da Correia Dutra. Não me lembro o número do prédio. A gente pegou algumas roupas, colocou na sacola, pegou alguns documentos, tirou umas coisas da gaveta - a gente tinha uma sala com uma estante cheia de livros - e nós descemos pela escada. E a polícia subiu pelo elevador. Nós não fomos presos naquela circunstância por causa disso: a visáo que ele tinha de que o Golpe estava sendo preparado - como realmente foi - e que, ao contrário da direção do partido, que achava que náo, que eles iam entrar e iam atrás dos dirigentes. A gente escapou por causa disso: a visão que ele tinha de que o Golpe estava sendo deflagrado. Nós saímos, fomos para o Méier, para a casa de uma família operária que nos alojou. Até quando ele recebeu o tiro no cinema. Esse é um episódio que também marcou muito aquela época.

\section{Clarice Herzog}

Viúva de Vladimir Herzog, jornalista assassinado em 1975, no DOI-Codi de Sáo Paulo. A versáo oficial alegava que ele tinha se suicidado. $O$ caso teve repercussáo nacional e internacional. 
Ah, eu tenho muitas lembranças, eu já era, estava na faculdade. Foi em 1964. Eu estava doente quando foi invadida a faculdade, e foi uma coisa que eu sofri muito, não ter presenciado aquilo, não ter vivido aquilo, o desespero de quem está lá na hora. E eu estava no [jornal] Última Hora, e a Última Hora foi invadida também, enfim, a gente viveu isso muito de perto, muito de perto. Nesse momento a gente começou a pensar seriamente em sair do país, porque o Vlado sempre foi de esquerda, não era de partido, mas nós sempre fomos de esquerda, não pertencíamos a nenhum partido, mas éramos de esquerda. E ele era muito... $\mathrm{E}$ começou a encontrar muito problema no Estadão, onde ele trabalhava. Aí, tentou ir embora. Primeiro tentou ir pro Chile, foi para o Chile, foi lá ver possibilidade de trabalho. Tinha brasileiro caindo por tudo quanto é canto, necessitando ficar lá muito mais do que a gente, porque nos tínhamos emprego aqui. Ele voltou e depois foi trabalhar para a BBC, a gente morou em Londres dois anos e meio, meus filhos nasceram lá.

(...)

E em 1968 a gente achou que estava havendo um respiro, uma possibilidade, os próprios estudantes estavam saindo em greves, passeatas, estava havendo um relaxamento aqui da ditadura, e a gente decidiu voltar. Eu voltei antes com os meus filhos.

E resolvemos voltar em 1968 e sete anos depois ele é assassinado.

Eu decidi que eu ia provar que o Vlado tinha sido assassinado, eu nunca tive dúvidas disso. E aí, eu comecei, procurei advogados, foi também uma coisa complicada, porque eu nunca tinha tido contato com um advogado, depois eu descobri que para um advogado virar seu advogado, você tem que passar uma procuração. Então, em advogados, eu fui várias vezes, eu achava que era meu advogado, e chegava uma hora ele caía fora, porque entrava eu e o sindicato.

(...)

O sindicato falava com o advogado que ia entrar com uma ação contra a União. Quando o sindicato caiu fora o advogado caiu também. O sindicato disse que não podia entrar, que tinha um recado de Brasília, se ele entrasse, o sindicato ia ser invadido. Aí, caiu esse advogado, então fui para outro, fui lá, falei com ele e ele disse: "Isso aí, só quando tiver o tribunal de Nuremberg". Eu falei: "Eu não vou ficar esperando por um tribunal de Nuremberg". Eu estava desesperada. (...)

Foi ideia do Bermudes (advogado) entrar com uma ação não de indenização, mas de responsabilidade pela prisão ilegal, tortura e morte. E eu ganhei essa ação. Consegui provar! 


\section{Dom Waldyr Calheiros}

\section{Dom Waldyr foi um bispo envolvido com a luta por direitos humanos durante a dita- dura militar. Atuou na baixada fluminense e em Volta Redonda.}

A lembrança que eu tenho é o seguinte. A igreja de São Francisco Xavier era uma igreja tida pelos militares como a igreja deles. Porque Caxias, quando na guerra que teve com o Paraguai, Caxias volta e encontra a igreja em ruínas. O festejo que o Exército preparava pela vitória - vitória interrogação - a vitória do Brasil no Paraguai, as festas que foram preparadas, Caxias teria dito, estava escrito na frente da igreja em uma pedra que está gravado: "O soldado, quando a casa de Deus está em ruínas, não recebe festa”. Assim estava lá escrito isso que Caxias teria dito. E ali os militares faziam geralmente aqueles seus encontros. Quando chega a ditadura, aí o que eu me lembro é o seguinte. Vieram me comunicar. Aí eu digo: "É um desastre para o Brasil essa ditadura". Porque eu, durante o tempo de vigário, eu tive contato com a Ação Católica, que era o braço direito da renovação da Igreja dentro de todo aquele contexto antigo, e ali o contato com os intelectuais, com os operários, com toda a juventude, havia sempre um movimento, JAC, JEC, JIC, JOC, JUC, e ali a reflexão sobre a realidade que nós estávamos vivendo me deixava um pouco situado dentro do tempo que nós estávamos passando. Entáo casualmente eu disse no dia da notícia, eu na missa disse: "Olhe, é lamentável que nós estamos dentro em uma ditadura”. E o pior é que havia vários militares dentro da missa, assistindo a missa, se afastaram imediatamente de dentro da igreja. Com a exceção de um... chegou a ser coronel, coronel César, esse não! Esse já trabalhava comigo, já sabia a minha maneira de pensar e sabia também que eu tinha simpatia pela transformação que Jango estava querendo tentar fazer, principalmente rural.

\section{Dulce Pandolfi}

\section{Historiadora e professora, ex-militante da Açáo Libertadora Nacional (ALN) e ex-pre- sa política.}

Olha, Recife era uma cidade muito politizada e eu acho que isto me marcou muito, antes da minha adolescência, inclusive. Porque eu era bastante jovem quando acontece o Golpe, eu estava de quatorze para quinze anos, portanto o pré-golpe em Recife era uma situação muito politizada porque o governador era Miguel Arraes e tivemos também Pelópidas Silveira, que era um progressista do Partido Socialista que foi prefeito de Recife, depois o vice-governador, e tínhamos todo o contexto das Ligas Camponesas.

(...)

eu estava falando que eu acho que o dia do golpe foi um dia muito especial, marcou muito também, porque eu lembro muito das tensôes. A gente era vizinho de Pelópidas Silveira, 
entâo ficou aquele clima: "vai ter um golpe, os militares vão pegar o poder", mas também não se acreditava, porque a esquerda tinha a grande ilusão de que as suas forças eram maiores do que eram de fato e de que nada barraria aquele avanço do progresso. A ideia era a de que estávamos do lado do bem e do progresso e de que tudo caminharia para uma solução que não fosse uma solução golpista de ditadura militar.

A gente estava indo para o colégio no dia 31 e quando meu pai nos levava de carro para lá encontramos com o Pelópidas e ele disse "não, vocês podem ficar tranquilos que a situação aqui em Pernambuco está sob controle". Tinha-se a ideia de que até o Exército tinha um lado progressista e que, portanto, estas forças iriam barrar qualquer atitude golpista que viesse, porque já tinha o bochicho de [que] um golpe havia sido preparado, mas que todo mundo poderia ficar tranquilo. Só que o golpe veio. E eu lembro de muitas pessoas próximas fugindo, de livros sendo queimados, enfim, foram uns dias muito tensos na minha vida. Eu lembro que voltar para o colégio foi muito sofrido para mim, porque eu não queria voltar para o colégio e enfrentar aquelas meninas reacionaríssimas que iam debochar de mim, eu que andava com aquele bóton do governo Arraes. Nesta altura Arraes já tinha sido preso, várias pessoas já tinham sito detidas e eu volto para o colégio e lembro que chegando lá encontro com uma colega de turma que vira para mim e diz assim: "Cadê o seu governador, aquele com cara de mamão?". Porque Arraes tinha aquele rosto assim sisudo, nossa, eu parti para cima dela, cheia de si, e nós fomos apartadas pelas freiras, eu disse "eu falei que não queria voltar para o colégio!”.

\section{Ferreira Gullar}

José Ribamar Ferreira (Ferreira Gullar) é poeta, jornalista, escritor, crítico de arte e dramaturgo. Na década de 1960, fez parte do Centro Popular de Cultura (CPC) da União Nacional dos Estudantes (UNE). Foi preso pelo Ato Institucional de número 5 e, nos anos 1970, viveu no exílio em inúmeros países.

Bom, o golpe começou no dia anterior, no dia 31 de março. Nós estávamos no CPC, quando chegou a notícia de que as guarniçóes do Exército em Minas Gerais tinham se rebelado contra o governo do João Goulart. Então, se viu que ia começar aí um... Bom, então nós do CPC chamamos as pessoas, artistas e todas as pessoas ligadas a nós, de teatro, de cinema, para uma reuniáo, uma assembleia lá no CPC, na sede da UNE ali no Flamengo, para a gente discutir como resistir a esse golpe que estava se pronunciando aí. Entáo, nós ficamos em assembleia permanente ali. À noite, veio uma comissão de intelectuais nos informar que estava tudo bem, que o golpe tinha fracassado, que o Exército estava leal ao João Goulart e tal, mas mal eles saíram metralharam a porta da UNE, feriram companheiros nossos, que nós levamos para o hospital às carreiras. E aí a coisa continuou. Uma parte ficou na UNE 
de vigília e eu fui para casa dormir com a Teresa, que era minha companheira, para no dia seguinte voltar para a UNE e substituir os outros que iam ficar tomando conta da sede da UNE. Quando eu acordei de manhã, que eu liguei o rádio, o golpe estava em marcha, praticamente consumado. Tinham tomado o forte de Copacabana. Mesmo assim eu peguei o meu carro e, junto com a Teresa e mais um companheiro, nós fomos para a UNE, para a [centro da] cidade para ver o que estava acontecendo. Eu fui até a Cinelândia, praça Marechal Deodoro, e estava cheio de tanques lá; os tanques ocupando. Mas a gente não sabia direito de fato o que estava acontecendo, se aquilo ali era para resistir ao golpe ou se aquilo ali era o golpe. Não sabia direito. E voltamos de carro, eu voltei pela praia do Flamengo, e pela pista da direita perto dos prédios, perto da calçada. E quando nos aproximamos da UNE, havia um tumulto e o carro não andava mais, porque estava o trânsito engarrafado. $\mathrm{E}$ andando pouco a pouco a gente viu que estavam atacando a UNE. Então, terminou que meu carro ficou parado em frente à UNE praticamente, pelo engarrafamento, e os caras passavam junto, rente à janela do meu carro com coquetel Molotov jogando na UNE. E nessa altura eu era presidente do CPC da UNE. Se eles me descobrem ali, eles tinham jogado um Molotov dentro do carro, não só na UNE. E então, nós ficamos ali naquela situação sem saber o que iria acontecer, até que o tráfego aliviou um pouco e nós conseguimos sair daquele aperto. Mas, à medida que nós nos aproximávamos aqui de Copacabana, havia uma verdadeira festa na cidade. Bandeiras saudando o golpe. Era uma coisa que a classe média inteira tinha apoiado. Bom, eu morava em Ipanema nessa época, nós fomos inteiramente arrasados para Ipanema sabendo que a UNE estava pegando fogo. Antes de dobrar a esquina nós olhamos, começava o incêndio lá na UNE e de modo que foi isso. À noite desse dia, que era dia primeiro, o Vianninha me ligou dizendo que ia haver uma reunião na casa do Carlinhos Lyra, que nós íamos nos reunir todos lá. Estava juntando o pessoal, com gente do partido que dava assistência, que participava, que era o Marcos Jaimovich. Aí nós fomos para essa reunião e eu então já saí de casa com a decisão tomada de me engajar na luta e entrar para o partido para participar da resistência contra a ditadura, contra o golpe que estava se dando ali.

\section{Flavia Schilling}

Filha de Paulo Schilling, político ligado ao presidente Joáo Goulart, acompanhou o pai no exílio no Uruguai, onde integrou a organizaçáo guerrilheira Tupamaros. Foi presa nesse país onde permaneceu por oito anos, sendo libertada após intensa campanha do Comitê Brasileiro pela Anistia (CBA).

E quando o Brizola se elege deputado federal pelo Rio de Janeiro, meu pai acompanha novamente o Brizola para o Rio de Janeiro e nós vamos para o Rio de Janeiro também. E em 
final de 63, então a gente vive o golpe de estado no Rio de Janeiro. E essa é uma lembrança interessante porque uma das lembranças mais fortes que eu tenho da situação do golpe é a noite do comício da Central do Brasil, imediatamente antes ao golpe. Porque a gente morava no Leblon, que não era o que é hoje, era um dos bairros mais afastados da zona sul e que começando, de alguma maneira, na época, Copacabana era a região mais nobre e depois começava Ipanema, Leblon era meio suburbano ainda, não? E a gente morava na rua Carlos Góis, no Leblon, na esquina com a rua Ataulfo de Paiva e ao final da rua havia uma favela. Era a favela do Pinto, se eu não me engano, que a polícia tinha removido. E essa noite do comício da Central do Brasil para mim é absurdamente marcante. Nessa época eu não tinha completado doze anos. As esquinas ficaram absolutamente repletas de velas acesas. E as pessoas orando de temor da chegada do comunismo no país. Então essa uma lembrança absurdamente marcante do Rio de Janeiro daquele momento do pré-golpe. E isso é muito marcante porque até hoje, imaginem, eu vou ao Rio daqui a dois dias. O Rio tem para mim uma coisa assim: não é de confiança porque as pessoas apoiaram o golpe de estado. Porque foi um apoio muito intenso. Náo era uma ou duas pessoas, eram centenas de pessoas nas esquinas acendendo velas para afastar a ameaça do comunismo, estendendo panos brancos pela janela. Entáo foi um momento muito marcante, naquela sensaçáo de pertencer a uma minoria, na verdade, que propunha outros rumos para o país, né? Então essa é uma lembrança pré-golpe.

\section{Magda Neves}

\section{Socióloga e professora universitária, foi militante estudantil e integrou o movimento pela anistia.}

(...) Meu pai foi um militar de carreira, mas o meu pai sempre foi um democrata e na época da revolução de 64 ele estava em Juiz de Fora servindo. Aí tinha o general Mourão Filho que saiu lá de Juiz de Fora com as tropas em direção ao Rio, mas papai foi contra o golpe. Ficou preso em casa, foi daqueles militares que náo concordaram com o golpe de 64. A gente tinha dois soldados na porta da nossa casa e a gente, eu me lembro, eu e ele, escutando a rádio de Brizola, a rádio lá do Rio Grande do Sul, a gente ficava assistindo e procurando notícias e tal. Depois disso ele foi aposentado compulsoriamente, então em nenhum momento ele compartilhou com a ditadura militar. Ele sempre teve esse espírito muito democrata e ele nos educou assim, nesse espírito democrata, de participaçáo. Ele sempre participou das atividades políticas lá de Juiz de Fora, ele gostava de ter encontros com políticos, de discutir os cenários da cidade, a vida da cidade e etc. E eu naquele momento, no chamado ensino secundário, evidentemente como muitos da minha geração estudei em colégio de freira, mas eu comecei a participar da Juventude Estudantil Católica, da JEC, e isso me abriu um horizonte de muitas questóes, de muito 
debate. Tinha toda aquela discussão da justiça, a justiça na sociedade brasileira, e eu carreguei isso muito fortemente, essa coisa da justiça. Depois quando eu entrei na universidade eu fui pra Juventude Universitária Católica, a JUC. Fui pra JUC, mas isso foi um pequeno momento porque logo depois teve um fechamento de todas as açôes católicas. Eu entrei na universidade em 1964, no ano do golpe, na [Universidade] Federal de Juiz de Fora. Eu fiz Serviço Social. Porque o curso de Ciências Sociais ainda náo existia lá e eu queria algum curso que tivesse voltado pras questóes sociais, isso pra mim era fundamental. Aí fui fazer Serviço Social e participei do DA [Diretório Acadêmico], fui presidente do DA da minha escola. Participava em todas as manifestaçốes em Juiz de Fora, nas ruas, contra ditadura. Porque entre 64 e 68, que foi o período que eu estive na faculdade, ainda tinha manifestaçóes de rua mesmo que controladas, mesmo que os guardas fossem atrás da gente, a polícia etc., a gente tinha ainda possibilidade de fazer manifestaçóes. Em todas eu estava, como presidente do diretório do Serviço Social e depois eu fui pro DCE, participei da diretoria do DCE em Juiz de Fora e quase fui pra Ibiúna, eu só não fui para o congresso de Ibiúna em 68 porque eu estava formando e a gente discutiu no DCE que devia ir uma pessoa que teria continuidade no movimento estudantil, então eu fui trocada naquele momento e não fui pra Ibiúna. Senáo teria sido presa ali naquele momento como muitos foram. O meu período em Juiz de Fora foi um período de muita participaçáo política, minha época de faculdade mesmo no período da ditadura já foi uma época de muita participação. Foi antes do AI-5.

\section{Maria José Nahas}

\section{Ex-militante da organização Comando de Libertaçáo Nacional (Colina), ex-presa po- lítica e ex-banida.}

Tenho, eu já estava aqui na época do golpe. Eu morava numa pensão que era ali na [avenida] João Pinheiro - você para sair da Afonso Penna e chegar no Palácio da Liberdade, você passa pela avenida João Pinheiro. Então, aquelas passeatas da TFP [Tradição, Família e Propriedade], as passeatas do terço, de náo sei o quê, tudo passava por ali e eu era espectadora, achava tudo aquilo um negócio meio ridículo, mas eu só era observadora. Quando eu entro na Escola, não era só a questão do golpe, mas tudo o que estava acontecendo naquele final dos anos 1960: A questão da Guerra do Vietnã, a questão do assassinato do Kennedy, os direitos civis, os Panteras Negras e por aí vai! A Primavera de Praga depois, nouvelle vague, quer dizer, é todo um caldo que você está ali dentro, você querendo ou não. Eu entrei nesse caldo, por influência de alguns companheiros brilhantes, como o Ângelo Pezzuti, que morreu no exílio, era uma pessoa brilhante. $\mathrm{Na}$ escola, houve toda essa aproximaçáo. E a Escola de Medicina nessa época teve muito militante da Colina [Comando de Libertação Nacional]. Eu era militante da Colina também. 


\section{Victória Grabois}

\section{Filha, irmá e viúva de desaparecidos políticos, integrante do Grupo Tortura Nunca} Mais.

(...) E aí, a minha mãe estava com o meu irmão André em casa, e foi para a casa de um outro amigo nosso, Afonsinho, que depois chegou a ser deputado pelo PDT, dormiu na casa dele. De manhã, ele teve que acordar minha mãe e o André e saíram porque ele ficou sabendo que a casa dele também ia ser invadida. A minha casa foi invadida no dia 2 de janeiro, ${ }^{11}$ eu morava com a minha tia, irmã do meu pai, em Botafogo, passava a semana e ia para casa sábado e domingo porque tinha que chegar na faculdade sete horas da manhã e tinha que atravessar de barca. Eu e minha tia, com esse sobrenome Grabois, ficamos com medo de chegar e o Exército estar lá, aí fui para casa de uma tia, irmã de minha mãe que morava na Tijuca. Meu pai tinha sumido e depois meu pai e minha mãe se encontraram na casa de outra tia minha em Niterói. Em julho nós fomos para São Paulo, a família se encontrou em julho em São Paulo, já na clandestinidade, e no dia 16 de abril os quinze que tinham sido suspensos por tempo indeterminado e mais quatro, o mais famoso deles é o Elio Gaspari, os dezenove, nós fomos expulsos pelo conselho universitário da Faculdade Nacional de Filosofia e não podíamos entrar em nenhuma faculdade pública. Se quisesse voltar a estudar, que fosse numa universidade particular. Foi instaurado um IPM que eu não fui responder, poucos foram, porque quem respondia saía de lá preso. Ou seja, ceifou a vida de dezenove estudantes que foram chamados "Os dezenove da filosofia" que eram quinze homens e quatro mulheres, as mulheres eram a Raquel Teixeira, que hoje é da Casa de Rui Barbosa, prima de Aloísio Teixeira, que foi reitor da UFRJ até junho, eu, a Ieda Sales e a Regina.

${ }^{11}$ De fato, em 2 de abril de 1964. (N. E.) 